Journal of Strategic Management

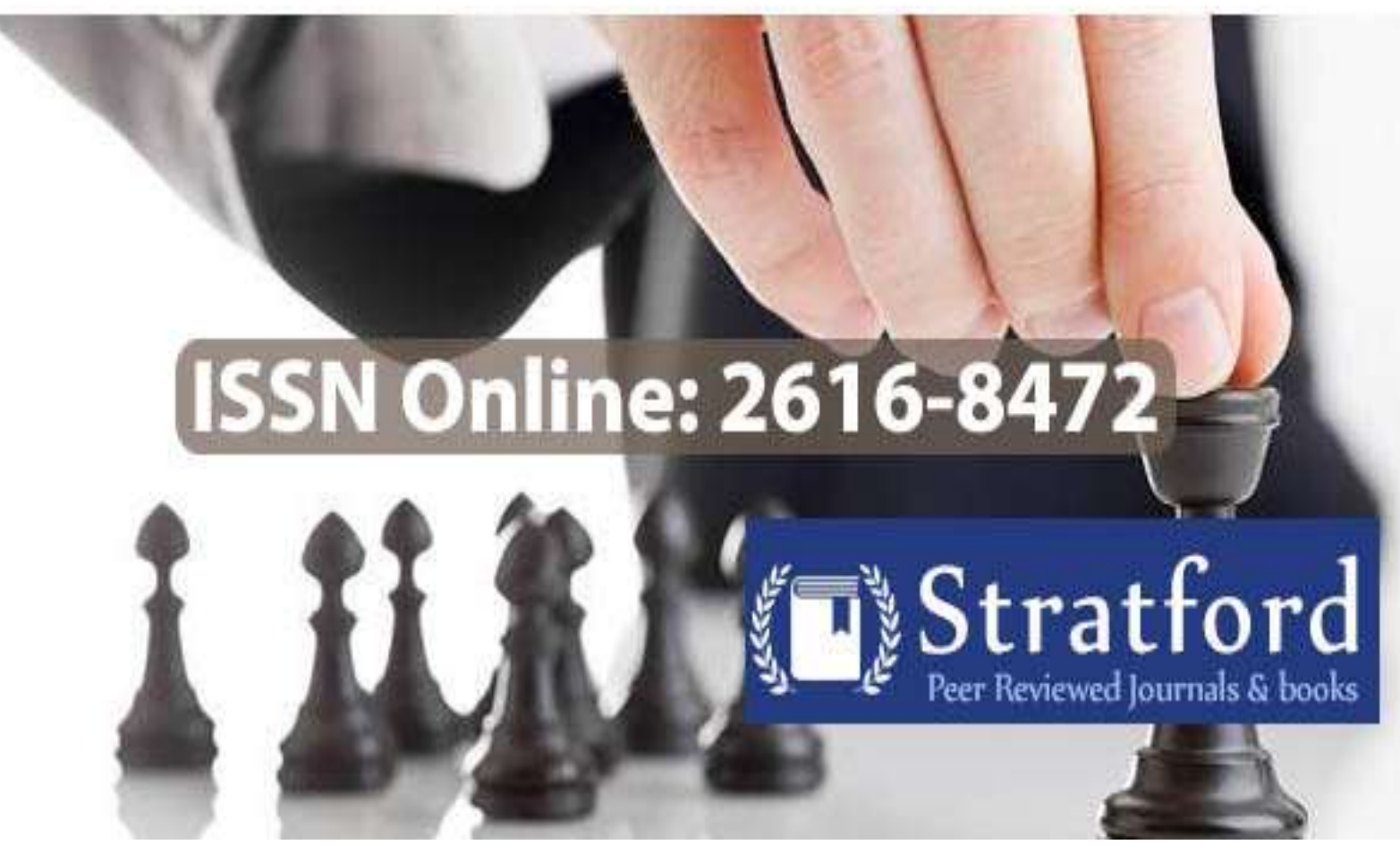

Strategic Innovation Practices and Profitability of Entrepreneurial Businesses: Perspective from Malaysia

Manicka Amir Fong

ISSN: 2616-8472 


\title{
Strategic Innovation Practices and Profitability of Entrepreneurial Businesses: Perspective from Malaysia
}

\author{
Manicka Amir Fong
}

\author{
Postgraduate, Universiti Utara Malaysia
}

Corresponding Author's email: fongamir@gmail.com

How to cite this article: Fong, M. A. (2021). Strategic Innovation Practices and Profitability of Entrepreneurial Businesses: Perspective from Malaysia, Journal of Strategic Management, 5(3), 26-43. https://doi.org/10.53819/81018102t4006

\begin{abstract}
More studies indicate that businesses becomes very competitive in an emerging market when they give importance to innovative activities that build their reputation in the market environment. Essentially, the key reason for innovativeness is the desire of firms to obtain increased business productivity and increased competitive edge and the ultimate goal of innovation is to improve business productivity. Strategic innovation is critical for firms that are in pursuit of improved productivity and their reward is often an increase in their profits and their market share. Process of strategic innovation is strongly associated with organizational learning and refers to ability of organization to generate, accept and implement new ideas, processes, products or services. The primary goal of process innovation is to generate a notable increase in productivity or to drive down costs significantly. This approach can help organizations achieve major reductions in process cost, improvements in quality, service levels and other business objectives. Strategic innovation is contributor to creation of new markets and products for the market, however even after the benefits of strategic innovation has been established the impact of strategic innovation on productivity of Businesses has remained misunderstood. The study adopted the use of mixed method approach research design which is the application of both qualitative and quantitative approaches. The study used a desk study review methodology where relevant empirical literature was reviewed to identify main themes. Result findings from literature-based review indicated that innovation had positive and significant influence on the productivity of businesses. It was recommended that innovation information should be available particularly to regulatory and advisory bodies for guidance to the Businesses on the need to craft and employ sound strategies geared towards continuously embracing innovativeness since innovation leads to improved financial productivity.
\end{abstract}

Keywords: Product Innovation, Service Innovation, Productivity. 


\subsection{Introduction}

A Successful organization knows the significance of strategic innovation in business (Kasemsap, 2017). Apple is a good example of how effective strategic innovation practice can improve your products and scale up your business. After reaching on the brink of collapse, it achieved new heights of success by implementing effective innovation management policy. The success of its innovative management strategies once again brought it in the league of leading organizations. If you are an entrepreneur who wants to learn from innovative management strategies of successful organizations, you need to consider adopting strategic innovation practices which will help see your business to the next level. According to Futterer, Schmidt and Heidenreich (2018), Innovative organizations are never complacent with their success. They always look for creative and novel strategies that could help them develop their working processes and enhance their products. As they are always open to new ideas, they are able to develop creativity around their working approach which enables them to serve their clients with better products.

Process of strategic innovation is strongly associated with organizational learning and refers to ability of organization to generate, accept and implement new ideas, processes, products or services (Osborne, Radnor, Kinder \& Vidal, 2015). Innovations in services are rarely radical and are mostly small improvements of products and processes. Process innovation involves rethinking an entire end-to-end process or with bringing a dramatic improvement to a valuable process segment (Hervas, Ripoll \& Boronat, 2014). The primary goal of process innovation is to generate a notable increase in productivity or to drive down costs significantly. This approach can help organizations achieve major reductions in process cost, improvements in quality, service levels and other business objectives (Torfing \& Triantafillou, 2016). These methods may concern changes in equipment, production organization or a combination of these changes and may be derived from the use of new knowledge. Process innovation leaves product functionality unchanged, while lowering the cost of production by a constant percentage (Von Krogh, Netland \& Wörter, 2018). According to Susanne (2015), Service innovation" has become a term referring to innovation taking place in the various contexts of services, including the introduction of new services or incremental improvements of existing services. Whilst service innovation can take place in the service sector, it does not necessarily need to. New and improved services can also be provided by non-services sectors, such as by manufacturing firms that aim at enlarging their supply portfolio with value adding services. Similarly, service innovation is intrinsically different from a "product", as it usually lacks the tangible nature of product innovations. Services may be highly tailored according to the client/customer needs, and include many different stakeholders

Olsen and Håkansson (2017) believe that innovative business is run by a creative team. Innovationminded managers recognize the power of a creative team and never hesitate to spend on their training. Effective innovation training programs motivate employees to find creative ideas that can improve work processes and enhance their productivity. According to Dooren, Bouckaert and Halligan (2015) business productivity is measuring organization's activities to produce an innovation, which also consists of organization's capability and the impact created by doing innovation. The impact of innovation activity on organization's productivity can occurs in various forms including productivity, service delivery, economic value, satisfaction and trust (Berman, 2015). Innovation productivity is the outcome of significant improvement implemented by the he

\section{https://doi.org/10.53819/81018102t4006}


organization such as efficiency, effectiveness and quality outcomes (Spekle \& Verbeeten, 2014). In addition, innovation productivity may also be viewed as a set of indicators used to diagnose the accomplishment of broad and specific objectives of innovation. Broad objectives usually include improvement in efficiency, quality and user satisfaction. Specific objectives may include addressing social challenges, fulfilling new regulations, and improving working conditions (Bloch \& Bugge, 2013). Examples of innovation impact in an organization are simplified administration, faster service delivery, increased user access to information, improved user satisfaction, improved employee satisfaction, and reduced cost (Rasul \& Rogger, 2017).

Ravichandran (2018) argues that truly successful innovative organizations integrate an effective IT infrastructure that enables smooth flow of information. Such a system ensures a seamless sharing of information and access to ideas which results in higher collaboration and better engagement across the organization. All innovation-friendly organizations practice a seamless systems and processes that support creativity at every step. A production manager cannot better the design of products if the finance department is not allowing sufficient budget to execute the process. Similarly, an IT manager cannot integrate an effective collaborative system in business applications if it lacks a supportive IT infrastructure. For a successful innovation strategy, all your processes and systems have to merge together to make your ideas a reality.

According to Acosta, Popa and Marqués (2016), executives should solicit new ideas from everyone at every level, both inside the organization and outside, top down and bottoms up. Business leadership and innovation implementation still need to be visible and supported by all management, through actions as well as messages. When innovations are driven by increased customer value and satisfaction, business growth will come naturally from repeat business, new customers, and referrals (Simon \& Yaya, 2012). Employees will be motivated by delighted customers, and the value will spread to the greater community and society. Geissdoerfer, Vladimirova and Evans (2018) asserts that too many innovations that aren't perfect the first time never get a second look, and die an expensive death. Others get caught in analysis paralysis, and never get exposed to real customers.

According to scholars in the past strategic innovation has no impact on the productivity of the SME (Pooja \& Singh, 2009). However, Ghouri et al (2020) in a study arrived at a conclusion that innovation contributed significantly on the productivity of the other major organization. Strategic innovation studies have been carried out in the Malaysia however most of studies have concentrated on the larger organizations such commercial banks (Juma et al., 2014). According to Juma et al., banks strategic innovations have not completely explored. This study however, focused on Businesses and the influence strategic innovation practices have on their productivity.

\subsection{Statement of the Problem}

Strategic innovation is believed to create superior productivity on the organization that adopts it (Walker, 2004). As a result of strategic innovation practices competitiveness has grown around the world in different business industries (Juma \& Lilly, 2014). Strategic innovation is therefore a way in which an incoming organization is able to compete with the already existing organizations (Juma \& Lilly, 2014). Therefore strategic innovation focuses on the organizations evolution overtime as it explores the unexplored positions in its industry (Larsen, Markides and Gary, 2002). Strategic innovation is contributor to creation of new markets and products for the market 
(Birkinshaw, Bouquet and Barsoux, 2011). However even after the benefits of strategic innovation has been established the impact of strategic innovation on productivity of Businesses has remained misunderstood (Juma et al., 2014). One reason is because the drivers of innovation have not been known and secondly is because innovation among the Businesses has not been tested.

According to scholars in the past strategic innovation has no impact on the productivity of the SME (Pooja \& Singh, 2009). However, innovation contributed significantly on the productivity of the other major organization. Strategic innovation studies have been carried out in the Malaysia however most of studies have concentrated on the larger organizations such commercial banks (Juma et al., 2014). According to Juma et al., banks strategic innovations have not completely explored. This study however, does not consider the SME setting and how strategic innovations influence their productivity.

A study carried out in Malaysia on strategic innovation was based in the insurance industry and concentrated more on the strategy that the insurance companies employed in their competitive environment. The studies discussed above concentrate more in different industries which have more income than that found in an SME. The second reason as to why they cannot be applied is because their target market is different as compared to that of an SME and therefore the strategic innovation applied is different in each case. This study therefore sought to establish the Influence of Strategic Innovation Practices on Productivity of Entrepreneurial Businesses in Malaysia.

\subsection{Specific objectives}

i. To establish the effect of product innovation on the Productivity of Businesses in Malaysia.

ii. To establish the effect of Service innovation on the productivity of Malaysia.

\subsection{Research Questions}

i. What influence does product innovation have on the productivity of Businesses in Malaysia?

ii. Does Service innovation have influence on the productivity of Businesses in Malaysia?

\subsection{Theoritical Review}

\subsubsection{Diffusion in Innovations Theory}

Diffusion of innovation theory was developed by (Rogers, 1971) and examines how ideas are spread among groups of people. Diffusion of innovations theory seeks to explain how, why, and at what rate new ideas and technology spread. Rogers argues that diffusion is the process by which an innovation is communicated over time among the participants in a social system. For Rogers (2003), adoption is a decision of "full use of an innovation as the best course of action available" and rejection is a decision "not to adopt an innovation". Rogers defines diffusion as "the process in which an innovation is communicated thorough certain channels over time among the members of a social system". As expressed in this definition, innovation, communication channels, time, and social system are the four key components of the diffusion of innovations.

Diffusion goes beyond the two-step flow theory, centering on the conditions that increase or decrease the likelihood that an innovation, a new idea, product or practice, will be adopted by members of a given culture. In multi-step diffusion, the opinion leader still exerts a large influence

\section{https://doi.org/10.53819/81018102t4006}


on the behavior of individuals, called adopters, but there are also other intermediaries between the media and the audience's decision-making. One intermediary is the change agent, someone who encourages an opinion leader to adopt or reject an innovation (Infante, Rancer, \& Womack, 1997).

Not all individuals adopt innovations in a social system at the same time. Instead, they tend to adopt in a time sequence, and can be classified into adopter categories based upon how long it takes them to begin using the new idea. Practically speaking, it's very useful for a change agent to be able to identify which category certain individuals belong to, since the short-term goal of most change agents is to facilitate the adoption of an innovation. Adoption of a new idea is caused by human interaction through interpersonal networks. If the initial adopter of an innovation discusses it with two members of a given social system, and these two become adopters who pass the innovation along to two peers, and so on, the resulting distribution follows a binomial expansion. Diffusion in Innovations. Diffusion goes beyond the two-step flow theory, centering on the conditions that increase or decrease the likelihood that members of a given society will adopt an innovation, a new idea, product or practice. Theory was relevant to this study since it articulates how ideas are spread among groups of people. It helped in explaining how, why and at what rate new ideas and technology spread among the Businesses within Kuala Lumpur County and how that influences their productivity.

\subsubsection{Theory of Technology Acceptance Model}

This theory was put forward by Davis (1986). According to the theory of technology acceptance model, developed the Technology Acceptance Model (TAM) that deals more specifically with the prediction of the acceptability of technology innovations systems. The purpose of this model is to predict the acceptability of technological innovations identify the modifications that must be brought to the system in order to make it acceptable to users. This model suggests that the acceptability of an information system is determined by two main factors: perceived usefulness and perceived ease of use. Perceived usefulness is defined as being the degree to which a person believes that the use of a system will improve his productivity. Perceived ease of use refers to the degree to which a person believes that the use of a system will be effortless. Several factorial analyses demonstrated that perceived usefulness and perceived ease of use could be considered as two different dimensions.

Technology Acceptance Model postulates that the use of an information system is determined by the behavioral intention, but on the other hand, that the behavioral intention is determined by the person's attitude towards the use of the system and by his perception of its utility (Marangunic \& Granic 2015). According to Davis, the attitude of an individual is not the only factor that determines his use of a system, but is also based on the impact that it may have on his productivity (Fishbein, \& Ajzen, 2014). Therefore, even if an employee does not welcome an information system, the probability that he will use it is high if he perceives that the system will improve his productivity at work. Besides, the Technology Acceptance Model hypothesizes a direct link between perceived usefulness and perceived ease of use. With two systems offering the same features, a user will find more useful the one that he finds easier to use.

According to Davis (1986), perceived ease of use also influences in a significant way the attitude of an individual through two main mechanisms: self-efficacy and instrumentality. Self-efficacy is a concept developed by Bandura (1982) which explains that the more a system is easy to use, the

\section{https://doi.org/10.53819/81018102t4006}


greater should be the user's sense of efficacy. Moreover, a tool that is easy to use will make the user feel that he has a control over what he is doing (Lepper, 1985). Efficacy is one of the main factors underlying intrinsic motivation (Bandura on 1982; Lepper, 1985) and it is what illustrates here the direct link between perceived ease of use and attitude. Perceived ease of use can also contribute in an instrumental way in improving a person's productivity. Because the user will have to deploy less effort with a tool that is easy to use, he will be able to spare efforts to accomplish other tasks. (Davis, 1986).

The technology acceptance model theory is relevant as it specifies behavioral beliefs, perceived usefulness and perceived ease of use of technological systems. In TAM, behavioral intention to use, leads to actual IT usage behavior. Behavioral intention is determined jointly by attitude and perceived usefulness, where perceived usefulness also affects attitude directly. The theory is relevant to the study in the sense that it would assist to portray how product innovations can be used to bring out improved productivity by Businesses in Kuala Lumpur.

\subsection{Empirical Review}

\subsubsection{Product Innovation and Productivity}

Osei et al (2016) conducted a study to establish the relationship between Product Innovation and Businesses Productivity in the Manufacturing Sector. The aim of the study was to establish the contribution of product innovation to the productivity and growth of Businesses in Iran. The study adopted quantitative approach using survey techniques to gather data from $400 \mathrm{SME}$ owner managers. The study results indicated that Businesses in the cities and with educated entrepreneurs were adopting product innovation at the expense of those in the rural areas. Evidence from the study supported the previously held view by Lau, Tang and Yam (2010) that product innovation leads to improvement of firm's productivity. The results of the study fitted very well the Ansoff Growth Model quadrant, where the introduction of new product and the improvement of existing ones were the center stage for Businesses growth both in the short and long run. The study concluded that, Businesses in Iran who adopted product innovative practices recorded a significant growth in terms of the annual turnover and the number of employees. It was further concluded that the survival of Businesses in Iran hinges on the adoption of innovative practices if they are to compete fairly with their larger counterparts and overseas competitors. The study recommended that, future research and directions should focus on the involvement of external support from the government and other support institutions for collaborations in the adoption of innovation.

Wadho and Chaudhry (2018) conducted a study on Innovation and firm productivity in developing countries: The case of Pakistani textile and apparel manufacturers. Using unique innovation survey data collected from a homogenous sample of firms in Pakistan, the study presented an analysis of the firm level determinants of product innovation and its impact on firm productivity. The study employed a multi-stage structural model linking the decision of a firm to innovate, its innovation investment, product innovation, and firm productivity using primary data from the textile and wearing apparel sector, which is the largest export sector of Pakistan. The study results indicated that, product innovation leads to increased labor productivity as well as higher labor productivity growth. The study further indicated that a 10 percent increase in innovative sales per worker was associated with a greater than 10 percent increase in labor productivity and labor productivity growth. The study concluded that larger firms were more likely to engage in innovation; however,

\section{https://doi.org/10.53819/81018102t4006}


there was no significant evidence that they invested more in innovation. It was further concluded that firms that are higher investment in innovation, that are more productive, and that introduce organizational innovations have higher innovative sales per worker. The study recommended that firms should invest more in innovation so as to realize improved productivity.

Ibrahim (2016) conducted a study on product innovation in Islamic banking and growth of Businesses in Kuala Lumpur. The study adopted an exploratory research design, the target Population was all banks in Malaysia that offer Islamic products. The study findings indicated that there was positive and significant relationship between product innovation in Islamic bank and the growth of Businesses in Kuala Lumpur. The study pointed out that there was improvement in response time to customer queries, research and development expenses were included in budget, use of flexible regulations had developed Islamic banking, banks uses Sariah advisory board to supervise transactions according to Islamic, the banks had a Sharia advisory committees/consultants to advise clients and that the growth indicators that affect Businesses were mainly government regulations investments, information networking, turn over, ICT adoption and Return on equity. The study concluded that the various financial innovations were indeed significant and had positively affected the growth of Businesses. It was recommended that Islamic banks should broaden product and service offerings by providing non-borrowing services, such as cash management, payroll management, payments, collections and trade finance solutions and the government should develop effective policies that will help the growth of Islamic banks in Malaysia.

Antonnet (2014) evaluated the effects of product innovation on financial productivity of commercial banks in Malaysia. The study was concerned with product innovation and its effects on financial productivity of commercial banks in Malaysia. The study adopted explanatory research design in which a population sample of 106 senior and branch managers from nine commercial banks was taken using the census method. Analyses were conducted through descriptive statistics and Ordinary Least Square technique to estimate a multiple regression equation. The regression results indicated that core product innovation and augmented product innovation did not have any relationship with the financial productivity of banks. The study revealed that all commercial banks had innovated and implemented products of each type even though there was a negative or no effect at all on their financial productivity and a certain amount of time might be necessary in order to observe the reflection of positive effects of innovative products on financial productivity. Based on the study results the study concluded with a suggestion of further and extended future research in product innovation and financial productivity of commercial banks in order to establish other useful findings that this particular study may have been unable to determine.

Olalere, Kes, Islam and Rahman (2021) conducted a study on impact of product innovation on financial productivity of commercial banks in Malaysia. The purpose of the study was to assess the impact of product innovation on commercial bank's financial productivity as the key players in the banking sector over a period of 4 years. The study adopted descriptive research design with a target population of 43 commercial banks in Malaysia as at 30th June 2011. Regression results indicated that there was a positive and significant relationship between innovated products Ratio and ROA. The study concluded that product innovations positively affect financial productivity. Based on the study findings, it was recommended that that product innovation information should

\section{https://doi.org/10.53819/81018102t4006}


be available particularly to regulatory and advisory bodies for guidance to the commercial banks on the need to craft and employ sound strategies geared towards continuously embracing innovativeness since innovation leads to improved financial productivity. Further the study recommends that firms should create an enabling environment for the employees to be innovative in their operations in order to utilize its competitive advantage so as to increase financial productivity and growth of the sector.

Spanos (2012) conducted a study dabbed antecedents of Businesses' product innovation productivity: a configurational perspective. The study examined antecedents of product innovation productivity in small and medium-sized enterprises (Businesses). The study was based on the resource-based theory. The study argued that because innovation is a complex and highly demanding activity, the capacity to innovate should be viewed as a configuration of tightly coupled functional and administrative competencies that together, not in isolation, explain product innovation. The study concluded that, technological collaboration with third parties is an effective means for Businesses to overcome their key liability with respect to innovation, that is, their endemic resource scarcity. The study's main contribution was to provide a more holistic view of SME's innovation behaviour by adopting a configurational perspective.

\subsubsection{Service Innovation and Productivity}

McDermott and Prajogo (2012) conducted a study dubbed Service innovation and productivity in Businesses using empirical data drawn from 180 managers in Australian service organisations. The study findings indicated that, controlled for size, neither of the innovation orientations showed significant, direct relationships with firms' productivity. However, ambidextrous innovation was positively associated with business productivity, indicating a synergy between exploration and exploitation. Further examination indicated the relationship between exploration/exploitation innovation and productivity was moderated by size within the sample of small firms. Taken together, the results of the study pointed to an interesting and complex relationship within Businesses in Australia relating to innovation orientation, size, and productivity. The study concluded that service Businesses are best served by the simultaneous pursuit of both exploitive and exploratory innovation. After assessing the relationship between ambidextrous innovation and productivity, the study recommended that there was need for creating balance and synergy between the two innovation types.

Aas and Pedersen (2014) conducted a study on the impact of service innovation on financial productivity. The study empirically investigated if firms focusing on service innovation perform better financially than firms not focusing on service innovation. Analysis of the financial productivity of 3575 Norwegian firms in the manufacturing industries supported the proposition that firms focusing on service innovation have significantly higher growth of operating results than firms not focusing on service innovation. However, this proposition was not supported in a corresponding analysis of 1132 Norwegian firms in the service industries. The study elaborated on these results by investigating a variety of productivity measures and by comparing the effects of service innovation between manufacturing and service industries.

Nasir (2016) conducted a study to establish the influence of human capital and service innovation advantage on business productivity: The moderating roles of dynamic and competitive environments. The purpose of the study was to examine the effect of human capital and service 
innovation advantage on business productivity in service sector firms, and how external environmental factors influence these relationships. The study adopted a cross-sectional mail survey of a random sample of Australian service firms with the unit of analysis being at the firm level. In total, 228 usable responses were received. The overall findings of the study showed that human capital was positively related to the creation of value or service innovation advantage which in turn resulted into rent generation for firms. The results further showed that the effect of service innovation advantage on business productivity was influenced by environmental dynamism and competitiveness with dynamic environments enhancing the effect while competitive environments weakening it. The findings of the study demonstrated the complementarity between the resources based theory and contingency theory as they clearly showed that the value of innovation as a firm's capability was enhanced or weakened within a business environment that is more dynamic or competitive. In conclusion, the study findings demonstrated the importance of human capital and service innovation and thus it was recommended that, managers should seek ways to harness and leverage human capital and adopting service innovation as a way of improving business productivity.

In Japan, Tseng, Wu, Chiu, Lim and Tan (2018) carried out a study on Service innovation in sustainable product service systems: Improving productivity under linguistic preferences. The study applied the fuzzy Delphi method. According to the study findings, there was a positive and significant relationship between service innovation and productivity. The study further indicated that, sustainable service innovation systems enable firms that are operating under resource limitations to deliver the best possible outcomes in terms of social well-being and economic growth. The study concluded by presenting four features that are included in the model which were sustainable consumption, collaborative advantage, innovation activities and service innovation capabilities. It was recommended that when building sustainable product service systems, firms should maintain operations and aim for business synergy in self-generated innovative products/services along with high-quality products/services, collaboration innovation and product and service innovations.

In China, Fu, Wang and Zhao (2017) conducted a study to establish the influence of platform service innovation on value co-creation activities and the network effect. The study adopted a multiple case study research design and an in-depth analysis of the case data was done using ATLAS.TI software. The study findings indicated a strong positive and significant association between service innovation and network effect. The study explained that, at the emergence stage, platform service innovations focus on building infrastructure. Platform owners stimulate the network effect directly via platform service innovations, rather than indirectly via value cocreation activities. At the expansion stage, the platform service innovations focus on building relationships among platform owner and different sides of participants. Platform owners stimulate the network effect indirectly, via value co-creation activities, rather than directly via platform service innovations. At the maturity stage, platform service innovations focus on building an environment for the platform ecosystem. The study concluded that, with service innovation, Platform owners stimulate the network effect indirectly, via value co-creation activities rather than directly. It was recommended that, managers need to consider the developmental stage of the platform, as a mismatching of stage of development (emergence/expansion/maturity) and focus 
(an orientation toward building infrastructure, relationships or environment) may lead to a failure to stimulate or enhance the network effect.

In a study by Moorthy, Tan, Choo, Wei, Ping and Leong (2012), service innovation was found to be one of the factors influencing the productivity of Businesses. The study was conducted in Malaysia to determine the Factors Affecting the Productivity of Businesses in Malaysia. Descriptive study was carried out to ascertain the implication of each independent factor towards the productivity of Businesses in Malaysia. A total of 300 sets of questionnaires were forwarded via email to the randomly selected Businesses in manufacturing industry all over Malaysia. The study findings indicated a positive and significant relationship between service innovation and the productivity of the Businesses. The study results supported the studies carried out by Keh et al.,(2007) and Cacciolatti et al., (2011), where they found that the good use of marketing information by the organization can lead to a higher probability of growth and enhance the competitiveness as well as a better decision making process. The study concluded that, effective entrepreneurship, appropriate HRM, use of marketing information and service innovation have a significant impact on the productivity of Businesses in Malaysia. The study recommended that, more effort should be devoted to study the factors affecting the productivity of Businesses in Malaysia for different sectors, such as mining and quarrying, services, construction, as well as primary agriculture.

Durst, Mention and Poutanen (2015) conducted a study dubbed Service innovation and its impact. The study applied the principles of a systematic review. The study results indicated that service innovation had influence on the productivity of firms. The study asserted that, with service innovation, companies can achieve a sustainable competitive advantage only by bundling novelties in terms of goods, with added value services. Those services also enable companies to increase customer loyalty and retention ( $\mathrm{Wu}, 2014)$, as they may also have the so-called lock-in effects, which have been explored in-depth in several service industries such as telecommunications and banking. The study concluded that the growing use of social media can also be regarded as a good starting point for the development of metrics. Many consumers share their opinions and experiences regarding services with their social network. It was therefore recommended that, Organizations should build on growing use of social media by monitoring the success of the service.

Chan and Quah, (2017) conducted a study on the influence of ICT-based service innovation on the operational productivity of commercial banks in Malaysia. The study adopted descriptive survey research design. The findings of the study showed that there existed a statistically significant relationship between ICT-based service innovations and operational productivity of the commercial banks in Malaysia. The study further indicated that, the emergence and growing penetration of ICT-based service innovation lead to the gradual realization of its great potential not only to improve the efficiency of established business processes of commercial banks, through which their usual tangible and intangible products and services are produced, but also to facilitate and drive important innovations in their processes, and also in their products and services. The study conclude that re-engineering particularly to old processes and services will not only revitalize banks products and processes, but also act as a form of organizational branding that is essential for productivity. 
Lim, Baharudin and Low (2017) conducted a study to determine the effects of financial innovations on the financial productivity of commercial banks in Malaysia. The study utilized descriptive research design. The results of the study indicated a strong positive and significant association between financial innovations and the productivity of the commercial banks. According to the study, banks in Malaysia had adopted the new technologies and modern ways of operating which is safer and superior compared to the old ones. This included use of EFT electronic payment transfer, automation in clearing through EFT, truncation or cheque imaging transmission use electronic banks transfer. The study also indicated that banks had been motivated by the different interests to pursue different financial innovations. Credit cards were being adopted by the banks so as increase income, profits, and to reduce credit and liquidity risks. The study concluded that banks use internet banking to improve accuracy and efficiency and to increase speed and reliability of the banking system. This is because the process is automated and is less prone to human errors. It was recommended that banks should adopt internet banking to increase their competitiveness and service quality. The study recommended that banks should strive to adopt the new technologies and modern innovation practices as one way of improving their financial productivity and enhancing their competitive advantage.

\subsection{Conceptual Framework}

Independent variables

\section{Dependent variable}

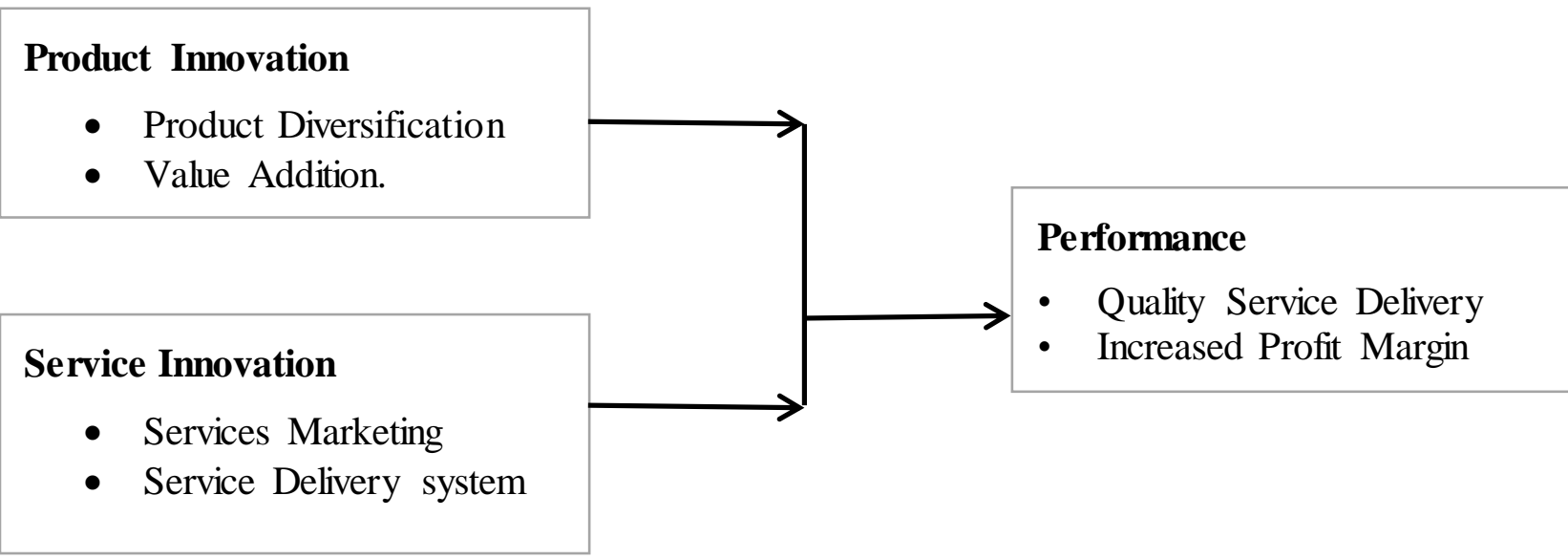

Figure 1: Conceptual Framework

\subsection{Research Methodology}

The study established Influence of Strategic Innovation Practices on Productivity of Entrepreneurial Businesses in Malaysia. The paper used a desk study review methodology where relevant empirical literature was reviewed to identify main themes. A critical review of empirical literature was conducted to establish the Influence of Strategic Innovation Practices on Productivity of Entrepreneurial Businesses in Malaysia.

\subsection{Results and Discussion of Findings}

Result findings from literature-based review indicated that innovation had positive and significant influence on the productivity. The results from the reviewed literature indicated that, product

\section{https://doi.org/10.53819/81018102t4006}


innovation leads to increased labor productivity as well as higher labor productivity growth. Larger firms were found to be more likely to engage in innovation; however, there was no significant evidence that they invested more in innovation. The results showed that firms that are higher investment in innovation, that are more productive, and that introduce organizational innovations have higher innovative sales per worker. The study findings also indicated that Businesses in the cities and with educated entrepreneurs were adopting product innovation at the expense of those in the rural areas and therefore the Businesses located in the rural areas recorded poor financial productivity compared to their counterparts in the cities who recorded improved financial productivity after adoption of the various strategic innovation practices.

The literature based results indicated that Businesses who adopted product innovative practices recorded a significant growth in terms of the annual turnover and the number of employees. Results of the study conducted on commercial banks indicated that, banks had been motivated by the different interests to pursue different financial innovations. Credit cards were being adopted by the banks so as increase income, profits, and to reduce credit and liquidity risks. The study concluded that banks use internet banking to improve accuracy and efficiency and to increase speed and reliability of the banking system. This is because the process is automated and is less prone to human errors.

Further results from reviewed literature showed that, the emergence and growing penetration of ICT-based service innovation lead to the gradual realization of its great potential not only to improve the efficiency of established business processes of commercial banks, through which their usual tangible and intangible products and services are produced, but also to facilitate and drive important innovations in their processes, and also in their products and services. Sustainable service innovation systems enable firms that are operating under resource limitations to deliver the best possible outcomes in terms of social well-being and economic growth.

More study results indicated that Businesses becomes very competitive in an emerging market when they give importance to innovative activities that build their reputation in the market environment. Essentially, the key reason for innovativeness is the desire of firms to obtain increased business productivity and increased competitive edge and the ultimate goal of innovation is to improve business productivity. Regression analysis results from the empirical literature assert that there exists positive and significant relationship between strategic innovation practices and the productivity of Businesses. Good use of marketing information by the organization can lead to a higher probability of growth and enhance the competitiveness as well as a better decision making process. Effective entrepreneurship, appropriate HRM, use of marketing information and service innovations have a significant impact on the productivity of Businesses.

The studies' findings shows that with service innovation, companies can achieve a sustainable competitive advantage only by bundling novelties in terms of goods, with added value services. Those services also enable companies to increase customer loyalty and retention as they may also have the so-called lock-in effects, which have been explored in-depth in several service industries such as telecommunications and banking. The findings established a positive and significant relationship between service innovation and productivity. It was revealed that sustainable service innovation systems enable firms that are operating under resource limitations to deliver the best possible outcomes in terms of social well-being and economic growth. 
According to a study finding, human capital was found to be positively related to the creation of value or service innovation advantage which in turn resulted into rent generation for firms. The results further showed that the effect of service innovation advantage on business productivity was influenced by environmental dynamism and competitiveness with dynamic environments enhancing the effect while competitive environments weakening it.

\subsection{Conclusion}

Based on the study findings from the empirical literature, it can be concluded that, the survival of Businesses in the current market conditions across the globe where there is serious competition is pegged on the adoption of innovative practices if they are to compete fairly with their larger counterparts and overseas competitors. From the empirical literature, it suffices to conclude that that Businesses use internet banking to improve accuracy and efficiency and to increase speed and reliability of the banking system. This is because the process is automated and is less prone to human errors. A conclusion can be made further that, re-engineering particularly to old processes and services will not only revitalize business products and processes, but also act as a form of organizational branding that is essential for productivity.

The study concluded that, Businesses becomes very competitive in an emerging market when they give importance to innovative activities that build their reputation in the market environment. Essentially, the key reason for innovativeness is the desire of firms to obtain increased business productivity and increased competitive edge and the ultimate goal of innovation is to improve business productivity. based on the study findings it can be concluded that, effective entrepreneurship, appropriate HRM, use of marketing information and service innovation have a significant impact on the productivity of Businesses. With service innovation, Platform owners stimulate the network effect indirectly, via value co-creation activities rather than directly. Conclusions can be made on the findings of the study that, service Businesses are best served by the simultaneous pursuit of both exploitive and exploratory innovation. Finally it can be concluded that larger firms are more likely to engage in innovation; however, there is no significant evidence that they invest more in innovation. Firms that are higher investment in innovation, that are more productive, and that introduce organizational innovations have higher innovative sales per worker.

\subsection{Recommendations}

Based on the study findings and conclusions, a number of recommendations can be made; Businesses should invest more in innovation so as to realize improved productivity. Businesses should broaden product and service offerings by providing non-borrowing services, such as cash management, payroll management, payments, collections and trade finance solutions and the government should develop effective policies that will help the growth of banks in Malaysia. A recommendation can be made further that, product innovation information should be available particularly to regulatory and advisory bodies for guidance to the Businesses on the need to craft and employ sound strategies geared towards continuously embracing innovativeness since innovation leads to improved financial productivity. Businesses should create an enabling environment for the employees to be innovative in their operations in order to utilize its competitive advantage so as to increase financial productivity and growth of SME sector.

Making reference to the study findings it can be recommended that, managers should seek ways to harness and leverage human capital and adopting service innovation as a way of improving

https://doi.org/10.53819/81018102t4006 
business productivity. when building sustainable product service systems, firms should maintain operations and aim for business synergy in self-generated innovative products/services along with high-quality products/services, collaboration innovation and product and service innovations. More effort should be devoted to study the factors affecting the productivity of Businesses for different sectors, such as mining and quarrying, services, construction, as well as primary agriculture. From the findings of the study it can also be recommended that, public and organizational policies should be designed in ways that addresses horizontal concerns and which generates better and viable inducement for innovation activities. Banks should strive to adopt the new technologies and modern innovation practices as one way of improving their financial productivity and enhancing their competitive advantage. 


\section{REFERENCES}

Antonnet, A. J. (2014). The Effects of Product Innovation on Financial Productivity of Commercial Banks in Malaysia (Doctoral Dissertation, School Of Business, University of Kuala Lumpur).

Birkinshaw, J., Bouquet, C., \& Barsoux, J. L. (2011). The 5 myths of innovation. MIT Sloan management review, 4, 1-8.

Bloch, C., \& Bugge, M. M. (2013). Public sector innovation-from theory to measurement. Structural change and economic dynamics, 27, 133-145.

Chan, J. K. L., \& Quah, W. B. (2012). Start-up factors for small and medium-sized accommodation businesses in Sabah, Malaysia: Push and pull factors. Asia pacific journal of tourism research, 17(1), 49-62.

Chan, J. K. L., \& Quah, W. B. (2012). Start-up factors for small and medium-sized accommodation businesses in Sabah, Malaysia: Push and pull factors. Asia pacific journal of tourism research, 17(1), 49-62.

Chen, K. Y., Hsiao, C. H., Chen, P. Y., \& Lee, C. F. (2018). The relationships among different types of market knowledge, ambidextrous learning, and different types of innovations. In Proceedings of International Academic Conferences (No. 8208758). International Institute of Social and Economic Sciences.

Durst, S., Mention, A. L., \& Poutanen, P. (2015). Service innovation and its impact: What do we know about?. Investigaciones Europeas de Dirección y Economía de la Empresa, 21(2), $65-72$.

Fu, W., Wang, Q., \& Zhao, X. (2017). The influence of platform service innovation on value cocreation activities and the network effect. Journal of Service Management, 28(2), 348-388.

Futterer, F., Schmidt, J., \& Heidenreich, S. (2018). Effectuation or causation as the key to corporate venture success? Investigating effects of entrepreneurial behaviors on business model innovation and venture productivity. Long Range Planning, 51(1), 64-81.

\section{https://doi.org/10.53819/81018102t4006}


Ghouri, A. M., Mani, V., Khan, M. R., Khan, N. R., \& Srivastava, A. P. (2020). Enhancing business performance through green human resource management practices: an empirical evidence from Malaysian manufacturing industry. International Journal of productivity and Performance management.

Harvey, M., Kiessling, T., \& Moeller, M. (2010). A view of entrepreneurship and innovation from the economist "for all seasons" Joseph S. Schumpeter. Journal of Management History, 16(4), 527-531.

Hervas-Oliver, J. L., Sempere-Ripoll, F., \& Boronat-Moll, C. (2014). Process innovation strategy in Businesses, organizational innovation and productivity: a misleading debate? Small Business Economics, 43(4), 873-886.

Kasemsap, K. (2017). Strategic innovation management: An integrative framework and causal model of knowledge management, strategic orientation, organizational innovation, and organizational productivity. In Organizational Culture and Behavior: Concepts, Methodologies, Tools, and Applications (pp. 86-101). IGI Global.

Lau, A. K., Tang, E., \& Yam, R. C. (2010). Effects of supplier and customer integration on product innovation and productivity: Empirical evidence in Hong Kong manufacturers. Journal of product innovation management, 27(5), 761-777.

Lilly, L., \& Juma, D. (2014). Influence of Strategic Innovation on Productivity of Commercial Banks in Malaysia: The Case of Malaysia Commercial Bank in Kuala Lumpur County. European Journal of Business Management, 2(1), 336-341.

Lim, S. C., Baharudin, A. S., \& Low, R. Q. (2017). Factors influence SMEs in Malaysia to adopt e-commerce: Moderating roles of perceived strategic value. Journal of Engineering and Applied Sciences, 12(6), 1566-1574.

Lim, S. C., Baharudin, A. S., \& Low, R. Q. (2017). Factors influence SMEs in Malaysia to adopt e-commerce: Moderating roles of perceived strategic value. Journal of Engineering and Applied Sciences, 12(6), 1566-1574.

Mabrouk, A., \& Mamoghli, C. (2010). Dynamic of financial innovation and productivity of banking firms: Context of an emerging banking industry. International Research Journal of Finance and Economics, 5, 2010.

\section{https://doi.org/10.53819/81018102t4006}


McDermott, C. M., \& Prajogo, D. I. (2012). Service innovation and productivity in Businesses. International Journal of Operations \& Production Management, 32(2), 216-237.

Moorthy, M. K., Tan, A., Choo, C., Wei, C. S., Ping, J. T. Y., \& Leong, T. K. (2012). A study on factors affecting the productivity of Businesses in Malaysia. International journal of academic research in business and social sciences, 2(4), 224.

Olalere, O. E., Kes, M. S., Islam, M. A., \& Rahman, S. (2021). The Effect of Financial Innovation and Bank Competition on Firm Value: A Comparative Study of Malaysian and Nigerian Banks. The Journal of Asian Finance, Economics and Business, 8(6), 245-253.

Olsen, P. I., \& Håkansson, H. (2017). The roles of deals and business networks in innovation processes. IMP Journal, 11(1), 25-50.

Prajogo, D. I., \& Oke, A. (2016). Human capital, service innovation advantage, and business productivity: The moderating roles of dynamic and competitive environments. International Journal of Operations \& Production Management, 36(9), 974-994.

Ravichandran, T. (2018). Exploring the relationships between IT competence, innovation capacity and organizational agility. The Journal of Strategic Information Systems, 27(1), 22-42.

Simon, A., \& Honore Petnji Yaya, L. (2012). Improving innovation and customer satisfaction through systems integration. Industrial Management \& Data Systems, 112(7), 1026-1043.

Soto-Acosta, P., Popa, S., \& Palacios-Marqués, D. (2016). E-business, organizational innovation and firm productivity in manufacturing Businesses: an empirical study in Spain. Technological and Economic Development of Economy, 22(6), 885-904.

Spanos, Y. E. (2012). Antecedents of Businesses' product innovation productivity: a configurational perspective. International Journal of Innovation and Regional Development, 4(2), 97-128. 
Tohidi, H., \& Jabbari, M. M. (2012). Product innovation productivity in organization. Procedia Technology, 1, 521-523.

Torfing, J., \& Triantafillou, P. (Eds.). (2016). Enhancing public innovation by transforming public governance. Cambridge University Press.

Truong, Y., Klink, R. R., Simmons, G., Grinstein, A., \& Palmer, M. (2017). Branding strategies for high-technology products: The effects of consumer and product innovativeness. Journal of Business Research, 70, 85-91.

Tseng, M. L., Wu, K. J., Chiu, A. S., Lim, M. K., \& Tan, K. (2018). Service innovation in sustainable product service systems: Improving productivity under linguistic preferences. International Journal of Production Economics, 203, 414-425.

Van Dooren, W., Bouckaert, G., \& Halligan, J. (2015). Productivity management in the public sector. Routledge.

Von Krogh, G., Netland, T., \& Wörter, M. (2018). Winning with Open Process Innovation. MIT Sloan Management Review, 59(2), 53-56. 